\section{$\underset{\substack{\text { hommes } \\ \text { \& migrations }}}{ }$}

\section{Hommes \& migrations}

Revue française de référence sur les dynamiques

migratoires

$1277 \mid 2009$

France - Allemagne

\title{
Le Chant des mariées
}

Film franco-tunisien de Karin Albou (2008)

\section{André Videau}

\section{Q OpenEdition \\ 1 Journals}

\section{Édition électronique}

URL : http://journals.openedition.org/hommesmigrations/185

DOI : 10.4000/hommesmigrations. 185

ISSN : 2262-3353

\section{Éditeur}

Musée national de l'histoire de l'immigration

\section{Édition imprimée}

Date de publication : 1 janvier 2009

Pagination : 138

ISSN : 1142-852X

\section{Référence électronique}

André Videau, «Le Chant des mariées », Hommes \& migrations [En ligne], 1277 | 2009, mis en ligne le 29 mai 2013, consulté le 22 septembre 2020. URL : http://journals.openedition.org/

hommesmigrations/185; DOI : https://doi.org/10.4000/hommesmigrations.185

Ce document a été généré automatiquement le 22 septembre 2020.

Tous droits réservés 


\title{
Le Chant des mariées
}

\author{
Film franco-tunisien de Karin Albou (2008)
}

\section{André Videau}

1 En 1942, Myriam et Nour - interprétées par Lizzie Brocheré et Olympe Borval - avaient 16 ans. Elles habitaient le même quartier populaire de Tunis où l'urbanisme oriental, avec ses imbrications, favorisait la promiscuité communautaire entre familles juives et musulmanes et influait sur leur mode de vie. Jusque-là, rien n'avait vraiment séparé les deux adolescentes ni porté ombrage à leur amitié fervente. Croyances, rites, coutumes avaient beau se distinguer dans les détails, ils se rejoignaient dans certaines pratiques, comportements et états d'esprit. Par exemple lors de la fréquentation rituelle du hammam, ou dans la mobilisation générale entourant les péripéties et les préparatifs d'un mariage. Pourtant, des changements se profilaient presque à l'insu des populations concernées. L'application des décrets Crémieux ${ }^{1}$ à l'ensemble des Juifs d'Afrique du Nord, fut ressentie comme un affront par les Indigènes musulmans qui se replièrent sur leurs singularités. La marche des évènements allait accélérer les dissensions. Myriam allait à l'école et savait lire. Nour était confinée dans l'espace privé ou devait porter le voile si elle s'aventurait dans la sphère publique. Ces disparités n'étaient pas suffisantes pour envenimer les relations entre les deux amies, les temps qui changeaient n'avaient pas encore d'emprise sur l'évolution naturelle de leur sensualité. Elles avaient le béguin pour Khaled, joli cœur du voisinage - joué par Najib Oudghiri. Le risque était de passer de la complicité à la compétition. La guerre allait faire voler en éclats ce qui restait d'harmonie. La politique antisémite de Vichy s'installait en Tunisie, surtout pendant les six mois de l'occupation allemande. Tita, la mère de Myriam - rôle qu'assume humblement la réalisatrice - frappée par les lois d'exception, ne voit d'issue à leur disgrâce que dans un mariage arrangé avec Raoul, riche médecin israélite - que Simon Abkarian, multilingue et sans reproche, interprète. Le mariage est aussi une solution sécurisante pour Nour pourvu que Khaled décroche un gagne-pain, fût-ce en devenant indic pour les nazis.

2 Avec peu de moyens (la réalisatrice revendique d'avoir travaillé dans les conditions du cinéma tunisien), le film fonctionne sur le registre discret de la confidence intime. Entre les mélodies des chants nuptiaux et les rituels policés des rapports sociaux, il met 
à nu avec une audace peu coutumière, les élans secrets des corps et des cœurs, enchaînant des plans allusifs à hauteur des regards, à portée des voix, dans les méandres des habitations et des ruelles.

3 Une belle réussite qui prolonge avec modestie un cinéma très personnel inauguré avec La Petite Jérusalem (voir H\&M n 1259 - janvier-février 2006).

\section{NOTES}

1. Les décrets Crémieux, d'Adolphe Crémieux, désignent les décrets $n^{\circ} 136$ et $n^{\circ} 137 \mathrm{du}$ 24 octobre 1870, ayant trait à la citoyenneté française pour les "Israélites indigènes", les "Indigènes musulmans" et "les étrangers" résidant dans les départements français d'Algérie. Ces décrets instaurent la naturalisation immédiate, sans formalité et sans condition des juifs d'Algérie, mais pas des musulmans d'Algérie. Ces textes provoquent un énorme ressentiment, et marquent le début de la fracture entre les deux communautés en Algérie. En effet pour les Arabes musulmans, les conditions imposées rendent la naturalisation quasiment impossible et donnent de fait au colonisé un statut inférieur au colonisateur. 